\title{
The Impact of Recruitment and Selection Criteria on Organizational Performance. GN Bank, Greater Accra Region of Ghana as the Mirror.
}

\author{
Aphu Elvis Selase (Corresponding Author) \\ College of Public Administration, Huazhong University of Science and Technology, \\ Wuhan, Hubei, China 430074
}

Received: Feb. 5, 2018 Accepted: Sep. 4, 2018 Online published: Sep 11, 2018

doi:10.5296/jpag.v8i3.13637～URL: https://doi.org/10.5296/jpag.v8i3.13637

\begin{abstract}
:
This study investigates the impact of recruitment and selection criteria on performance using GN Bank, Accra Ghana as point of convergence. The analyses of 130 valid responses obtained through a questionnaire that was administered to randomly selected respondents uncovered that recruitment and selection criteria have significant effect on organization's performance $(\mathrm{X} 2=35.723 ; \mathrm{df}=3 ; \mathrm{p}<0.05)$. The more objective the recruitment and selection criteria, the better the organization's performance $(X 2=20.007 ; \mathrm{df}=4 ; \mathrm{p}<0.05)$. Therefore, its imperative to put candidates under meticulous check cum scrutiny so as to conceive an organizational palatability as the after-effect.
\end{abstract}

Keywords: impact, recruitment, selection, organizational performance, human resource, GN bank, Accra Ghana

\section{Introduction}

A standout amongst the most noteworthy improvements in the field of organizations lately is the expanding significance given to human resource. Individuals are fundamental to organizations as they offer viewpoints, qualities and credits to hierarchical life; and when overseen viably, these human characteristics can be of impressive advantages to the organization. As uncovered in Djabatey (2012) this situation loans confidence to the expanding consideration being paid to the general population as part of hierarchical riches. This is so on the grounds that the advancement of individuals, their abilities, and the procedure improvement of the aggregate organization are the support of human asset or human resource administration (Mullins, 1999; Djabatey, 2012). Likened to this improvement is the dispute in National University of Ireland (2006) that the proceeded with development of the endeavour relies upon its capacity to recruit and select top notch staff at all levels. 
While enlistment is the way towards distinguishing and pulling in potential applicants from inside and outside an organization to start assessing them for future work, choice starts when the correct gauge of hopefuls are recognized (Walker, 2009).

Notwithstanding, most recruitment and selection procedures have components of subjective judgment inalienable in them. In any case, treating work candidates in an expert and positive way will probably abandon them, regardless of whether they are effective or not, with a positive perspective of the organization and how it has managed the candidates (National University of Ireland, 2006). Experience likewise demonstrates that a fruitful arrangement can create comes about which affect positively on the more extensive parts of hierarchical life while a poor one can have harming impacts far outside the organization in which it is made. Notwithstanding, the recruitment and selection of workers additionally gives a chance to the organization to introduce itself in a greater light (National University of Ireland, 2006).

Accessible writing has contended that the accomplishment of the endeavour is straightforwardly connected to the execution of the individuals who work for that business. By a similar token, under-accomplishment can be a consequence of work environment disappointments. Since employing the wrong individuals or neglecting to suspect variances in enlisting needs can be exorbitant, it is vital that cognizant endeavours are put into human asset arrangement (Biles and Holmberg, 1980; Djabatey, 2012). It has likewise been contended that all together for the venture to construct and maintain the upper hand, legitimate staffing is basic (Djabatey, 2012). Along these lines, enlistment and determination have turned out to be basic in organizations since people should be pulled in on a convenient premise, in adequate numbers and with proper capabilities. Subsequently, this investigation sets to analyse the impact of recruitment and selection criteria on execution utilizing GN Bank as populace of premium. Keeping in mind the end goal to accomplish this target, I at that point estimated that: Recruitment and selection criteria have significant effect on organization's performance, the more objective the recruitment and selection criteria, the better the organization's performance.

Recruitment and selection are key elements of human asset administration for a business organization. These are terms that allude to the way toward pulling in and picking possibility for work. The nature of the human asset the firm has vigorously relies upon the viability of these two capacities (Gamage, 2014). Recruiting and selecting the wrong applicants who are not able to their tasks, accompanied an enormous negative cost which organizations can't bear. Consequently, the general point of recruitment and selection inside the organization is to get the number and nature of representatives that are required to fulfil the vital targets of the organization, at negligible cost (Ofori and Aryeetey, 2011).

As clarified by Opatha (2010), recruitment is the way toward finding and pulling in appropriately qualified individuals to apply for work opportunities in an association or organization. It is an arrangement of exercises an organization uses to pull in work competitors who have the required capacities and mentalities. Recruitment is the way toward producing a pool of qualified candidates for hierarchical employment opportunities. For Ofori and Aryeetey (2011), recruitment is the way toward creating a pool of able people to apply 
for work inside an association or organization. Proof has demonstrated that bigger enterprises are more probable than littler organizations in actualizing modern recruitment forms (Bacon and Hoque, (2005) with dominant part of littler associations depending on referrals and promoting as their enlistment practices of decision (Barber, Wesson, Roberso and Taylor, 1999).

The broadly useful of recruitment as indicated by Gamage (2014) is to give the organization a pool of possibly qualified employment applicants. The nature of human asset in an association exceedingly relies upon the nature of candidates pulled in light of the fact that the organization will choose workers from the individuals who were pulled in. In a similar vein, Henry and Temtime (2009) interpreted recruitment as the passage purpose of labor into an organization and the way an organization must take after from that point on with a specific end goal to ensure that they have pulled in the perfect people for their way of life and vibes so the general vital objectives are accomplished .

Then again, selection is the way toward settling on the decision of the most appropriate candidate from the pool of candidates selected to fill the important activity opening (Opatha, 2010). Selection is the procedure by which particular instruments are locked in to look over the pool of people most appropriate for the activity accessible (Ofori and Aryeetey, 2011). Selection includes the utilization of at least one strategies to evaluate candidate's appropriateness with a specific end goal to settle on the right choice and can be on the other hand observed as a procedure of dismissal as it rejects various candidates and select just a couple of candidates to fill the opening. Subsequently, choice capacity might be a negative capacity as opposed to a positive capacity (Gamage, 2014).

As per Gamage (2014) the targets of choice capacity are to get the opportune individual to the correct activity, build up and keep up a decent picture as a decent business, and keep up the selection procedure as savvy as could be expected under the circumstances. Selection is a critical angle to consider for organizations because of various reasons. Regularly the execution of organizations relates specifically to the general population working inside it, which means the opportune individuals should be enlisted to guarantee authoritative achievement (Henry and Temtime, 2009). It is likewise a costly procedure to enlist another person into the organization. So it isn't something associations need to put time and cash into just to discover they have contracted some person who isn't reasonable. It is imperative that organizations get the procedure right the first run through round, in light of the fact that assets are sufficiently rare as it seems to be. Choosing the correct candidate can be a troublesome errand, yet by the day's end, the organization's notoriety is held by the general population it utilizes (Henry and Temtime, 2009).

\section{Theoretical Framework}

This investigation lays on Human Capital Theory, Resource Based View Theory and Equity Theory. Human Capital hypothesis as proposed by Adam Smith (1723-1790) in Teixeira (2002) has the focal thought that individuals are settled capitals quite recently like machine since they have aptitudes and valuable capacities that has authentic cost and returns benefits. The start in the human capital hypothesis, as per Armstrong (2006) is that individuals and 
their aggregate aptitudes, capacities and experience, combined with their capacity to convey these in light of a legitimate concern for the utilizing organization, are currently perceived as making a noteworthy commitment to hierarchical achievement and furthermore constituting a huge wellspring of upper hand. Asset Based View (RBV) of Barney (1991) recommends that supportable upper hand is feasible when firms have a human asset pool which can't be imitated or substituted by rivals. As per the Resource-Based view, firms ought to continually assess their workforce to guarantee that they have the correct individuals with the correct aptitudes in the correct spots to guarantee maintained upper hand (Barney, 2001) and when this isn't the situation, firms should compensate for the deficiency by utilizing suitable recruitment and selection criteria. The hypothesis kept up that the real piece of any association's quality or shortcoming stem from the gauge of the general population utilized and the nature of their working connections. To this end, Boxall (1998) uncovered that organizations which enroll and hold outstanding people have the capacity of creating human capital preferred standpoint. As indicated by Sparrow et al., (2002), innovation and capital can be gained by most firms whenever, at a cost, yet it is difficult to obtain a prepared pool of profoundly qualified and propelled representatives. Accordingly, so as to be separated, the organizations should be extremely cautious with the recruitment and selection process.

Value Theory as proposed by Adams (1963), underlines the rule of decency. As indicated by the standards of the Equity Theory, the best recruitment and selection criteria in the organization is what depicts the firm as Equal Opportunity Employer.

Finding competent workers is an important organizational challenge (McEvoy, 1984; Deshpande \& Golhar, 1994; Atkinson \& Storey, 1994), with the difficulty centring on recruiting and selecting employees with the correct qualifications to help achieve goals (Priyanath, 2006). As further argued in Priyanath (2006) this problem is compounded by the lack of systematic method for recruiting and selecting employees. A systematic recruitment process according to Gamage (2014) involves identifying vacancies, job analysis, job description, person specification and advertising. As against informal process for recruiting and selecting employees, a systematic selection process involves the recruiting process, gathering information about qualified applicants, evaluating the qualification of each applicant and making decisions about employment (Gamage, 2014).

\section{Recruitment, Selection Criteria and Organizational Performance}

Recruitment and selection frame a noteworthy piece of an organization's general resourcing methodologies, which distinguishes and secures individuals required for an organization to survive and prevail in the short to medium-term (Elwood and James, 1996). Truth be told, the essential reason for recruitment is to make a pool of appropriately qualified possibility to empower the choice of the best contender for the organization, by drawing in an ever increasing number of workers to apply in the organization though the fundamental motivation behind selection process is to pick the correct possibility to fill the different positions in the organization (Gamage, 2014).

Accessible proof shows that there is a positive and noteworthy connection amongst recruitment and selection and the execution of an undertaking (Gamage, 2014). Sang (2005) 
for instance found a positive relationship amongst recruitment and selection and business execution. Such were additionally of positive outcomes amongst recruitment and selection and execution as observed in Ichniowski and Shaw (1999), Katou and Budhwar (2006) and Wright et al. (2005). Different examinations, for example, Syed and Jama (2012) have similarly demonstrated that executing a powerful recruitment and selection process is emphatically identified with hierarchical execution.

With particular reference to enlistment and choice (Recruitment and Selection) criteria cum hierarchical execution, Montana and Charnov (2000) kept up that recruitment and selection incorporate sourcing competitors by publicizing or different strategies, screening potential hopefuls utilizing tests and meetings, choosing applicants in light of the aftereffects of the tests or meets, and on-boarding to guarantee that the competitors can satisfy their new parts successfully. As per Huselid (1995) it is enlistment systems that give a vast pool of qualified candidates, matched with a dependable and legitimate choice administration that will have a generous impact over the quality and kind of abilities new workers have. The ramifications of this line of thought is that an organization's human asset strategies and practices speak to essential powers for forming representative conduct and states of mind.

For Gamage (2014) the selection practices will figure out who is employed. In the event that legitimately planned, it will recognize the able hopefuls and precisely coordinate them to the activity. The utilization of the correct selection gadget will build the likelihood that the perfect individual is filled with a space. At the point when the best individuals are chosen for the activity, efficiency increases. Little ponder on writing, for example, Terpstra and Rozell (1993) revealed of a positive relationship between the breadth of recruiting, choice test approval and the utilization of formal selection systems and firm benefits. Also, Rauf (2007) found that advanced recruitment and selection strategies are emphatically identified with execution in organizations.

Composing on a portion of the difficulties confronting recruitment and selection criteria in associations or organizations, István (2010) watched that there are a lot of procedures utilized as part of enrolment and employing today among which are a few techniques not acknowledged by specialists generally, or not suggested for the procuring procedure. As contended by István (2010), choice (selection) techniques can be assessed in a few ways. One conceivable approach is to look at enlisting (recruiting) systems on the premise of their legitimacy, unbiasedness, extent of utilization, and cost.

On the whole, Sinha and Thaly (2013) noticed that there is an assortment of enlistment approaches (e.g. worker referral, grounds enrolment, publicizing, enlistment offices/specialists, work destinations/entryways, organization sites, online networking and so forth.); and most organizations will utilize a blend of at least two of these as a component of an enlistment procedure or to convey their general recruitment methodology. Be that as it may, which enlisting or recruiting channels ought to be utilized relies upon the activity position, on the organization's manager image, on the assets the organization has on its enrolling group, on what amount of selecting spending plan the organization has, and so forth. One can utilize them all and discover which suits the best. Each enrolling channel offers distinctive 
advantages and impediments and works better for specific circumstances and organizations. The key is gathering continuous enlistment measurements on these selecting channels to make sense of what works best for the organization in various circumstances. The enlisting background of each organization is extraordinary and the most ideal approach to make sense of what works best is to dissect measurements in light of the past selecting endeavours, not the endeavours of every other person. Once the organization has its enrolling measurements arrangement set up, the time has come to begin utilizing the enlisting channels that the organization thinks will work for it game plan (Sinha and Thaly, 2013).

\section{Recruitment and Selection Quality and Organizational Performance}

The viability of various recruitment and selection criteria of workers has been the subject of research for more than 60 years (Sinha and Thaly, 2013). The viability has essentially been surveyed by looking at the rates of turnover, work survival and occupation execution alongside hierarchical issues, for example, referrals by current faculty, in-house work postings, and the rehiring of previous representatives (Zottoli and Wanous, 2000).

The study by Sen and Saxena (1997) has stressed the significance of a quality procedure amid the season of recruitment and enlisting given that the correct sort of work is difficult to find. Truth be told, while loaning belief to the significance of enlisting quality competitors who are elusive, Tendon (2006) cautioned that ability inadequacy is inconsequential to gigantic populace. While announcing that recruitment is the main part to attract and holding information of workers, Unwin (2005) offered noteworthiness to the procedure required amid the season of enlisting and employing great candidate(s).

In spite of the fact that the investigation led by Subbarao (2006) clarified the recruitment sources utilized by singular employment searchers at different levels, the examination additionally featured the significance of various sorts of methodologies utilized at the season of enlistment which thus makes any organization well established or less settled. As per Sarkar and Kumar (2007) hierarchical execution is relied on the approach which the organization receives in the recruitment and selection of workers. To this end, Sarkar and Kumar (2007) talked about a comprehensive model of enlistment i.e. stressing the significance of the entire procedure of recruitment and the interdependence of its parts (Sinha and Thaly, 2013).

Vyas (2011) declared that the present pattern is that organizations are searching for techniques for decreasing the time and exertion in the recruitment and selection process. In any case, Munyon, Summers, Ferris and Gerald (2011) counselled that techniques for group staffing should make an interpretation of upper hands to an organizations. In comparative vein, DeVaro (2008) showed that recruitment methodologies can prompt positive hierarchical results. For Sinha and Thaly (2013) receiving subjective framework in enlistment and determination has helped organizations to develop as they have possessed the capacity to get the perfect individuals for their opportunities. What's more, the fitting channels have instrumented the organizations to get the extraordinary and fluctuated sources to which they can swing to for successful contracting (Sinha and Thaly, 2013). 
Recruitment and selection in any organization is a genuine business as the achievement of any organization or proficiency in benefit conveyance relies upon the nature of its workforce who was enlisted into the organization through recruitment and selection activities (Ezeali and Esiagu, 2010). Since recruitment and selection include getting the best candidate for an occupation (Obikeze and Obi, 2004), it has been underlined that enlistment systems that give an expansive pool of qualified candidates, combined with a solid and legitimate choice administration, will have a generous impact over the quality and sort of abilities new representatives have (Okoh, 2005). For Mullins (1999) the essential thing is for some reasonable arrangement to be utilized, agreeing to every single legitimate prerequisite identifying with work and equivalent open doors, to take after prescribed codes of training and to guarantee equity and reasonable treatment for all candidates.

Bohlander, Snell and Sherman (2001) detailed that it is critical for supervisors to comprehend the destinations, arrangements and practices utilized for choice. All the more significantly, those in charge of settling on determination choices ought to have satisfactory data whereupon to base their choices. As Robbins (2005) watched, organization's human asset approaches and rehearses speak to critical powers for moulding representative conduct and demeanours. As indicated by Okoh (2005), not only that authoritative choice practices figure out who is enlisted, the utilization of the correct determination criteria will build the likelihood that the perfect individual will be picked. At the point when the best individuals are chosen for the activity, profitability expands (Osemeke, 2012).

Further, time is also a great zonal arena to consider when employing the exercise of recruitment and selection process in an organization. As (Aphu E. S. 2015) indicated, if you inject time as an antidote in your daily dealings, you will always have healthy moments cum fruitful results. Therefore, time ought to be adhered to in as much as recruitment and selection are of great concern in an organizational performance, achievements and thereby encapsulating productivity.

\section{Methodology}

This study adopted survey research design and structured questionnaire was used to collect data. The research population covered six (6) main business branches of GN Bank in Greater Accra Region. The respondents covered top, middle and lower positions workers in marketing and operation sections of the bank. The six (6) business branches in Greater Accra include Achimota Branch, Abokobi Branch, Circle Branch, Kaneshi Branch, Spintex Branch and Tema Branch. There are 3,756 full time employees at GN Bank. It is instructive to note that out of the 3,756 full time employees at GN Bank, 1,315 (35\%) of GN Bank contract employees are engaged in Greater Accra Region while the remainder are engaged in rest of the country. Random sampling technique was used to select every element of the population in the business branches. A total of sixteen (16) full staff and six (6) contract staff were selected using correspondent serial number selected from the table of random numbers. A total of one hundred and thirty two (132) copies of questionnaires were administered out of which one hundred and thirty (130) copies were validly filled and returned. Data was analysed using descriptive and inferential statistics. Chi-square was used to test the 
relatedness of the hypothesis.

\section{Results}

The outcomes from the examination showed a solid understanding $(100 \%)$ that the bank has an approach which manages the recruitment exercises. Out of the one hundred and thirty respondents, $72.3 \%$ concurred that the bank recruits promptly positions are proclaimed empty. In any case, $53.1 \%$ of the members announced that the bank staff are not generally mindful of the current opportunities in the bank. That is, data identifying with existing opportunities isn't conveyed to the grapevine by the administration. This data hole, as indicated by the outcome, happens because of non-contribution of workers in settling on choices viewing recruitment of staff as detailed by $69.2 \%$ of the members. With respect to question of whether recruitment and selection criteria have critical impact on organization's execution, $46.2 \%$ were of the view that recruitment and selection criteria influence the organization's execution. The outcome additionally demonstrated that $56.9 \%$ announced that the bank supports the impact of outside variables amid the choice procedure. It was likewise found by the perspective of $62.3 \%$ of the respondents that the bank does not recognize all application letters as an indication of reality on its part. Reacting to the inquiry whether target recruitment and selection criteria influences the bank's execution, $48.4 \%$ detailed that the more goal the recruitment and selection criteria, the better the organization's execution. Besides, $69.2 \%$ of the members differ that loan applicants with important abilities are considered amid the determination procedure in the bank. This means notwithstanding important aptitudes, different components are additionally considered amid the determination procedure of the bank. On the topic of straightforwardness in the short-posting of employment competitors, $62.3 \%$ revealed that the recruitment and selection process is straightforward in connection with short-posting of occupation hopefuls in the bank. The outcome on the trial of theories demonstrated that recruitment and selection criteria have huge impact on firm's execution $(\mathrm{X} 2=35.723 ; \mathrm{df}=3 ; \mathrm{p}<0.05)$. The more goal the recruitment and selection criteria, the better the firm's execution $(\mathrm{X} 2=20.007 ; \mathrm{df}=4 ; \mathrm{p}<0.05)$.

\section{Implications}

The discoveries of this investigation is couple with existing data in the writing that recruitment and selection criteria have noteworthy impact on organization's execution. Huselid (1995) watched that recruitment and selection criteria have noteworthy authoritative execution impact because of the arrangement of vast pool of qualified candidates: matched with a solid and legitimate choice it has a generous impact over the quality and sort of aptitudes new representatives have. Correspondingly, Gamage (2014) noticed that the enlistment and determination practices will figure out who is procured, shapes representative conduct and state of mind. On the off chance that legitimately composed, it will distinguish capable competitors and precisely coordinate them to the activity.

The utilization of the correct selection gadget will expand the likelihood that the ideal individual is filled a space. At the point when the best individuals are chosen for the activity, efficiency increments. As per Rauf (2007) Terpstra and Rozell (1993) there is a positive relationship between the breadth of enrolling, determination test approval and the utilization 
of formal choice methodology, organizations execution and firm benefits. Rauf (2007) additionally agreed that complex recruitment and selection methodology are decidedly identified with execution in organizations. In like manner, Okoh (2005), not only that authoritative determination rehearses figure out who is enlisted, the utilization of the best possible selection criteria will expand the likelihood that the ideal individual will be picked. At the point when the best individuals are chosen for the activity, efficiency expands (Osemeke, 2012).

\section{Conclusions cum Recommendations}

Recruitment and selection in any organization is a genuine business as the achievement of any organization or productivity in benefit conveyance relies upon the nature of its workforce who was enlisted into the firm through recruitment and selection works out (Ezeali and Esiagu, 2010). Bohlander, Snell and Sherman (2001) revealed that it is imperative for directors to comprehend the targets, approaches and hones utilized for selection. All the more critically, those in charge of settling on selection decisions ought to have satisfactory data whereupon to base their choices. As Robbins (2005) watched, organization's human resource approaches and hones speak to critical powers for forming worker conduct and dispositions. In perspective of the discoveries, the examination recommends that in outlining and organizing enlistment and selection criteria quality ought not to be bargained. This is all the more so as the correct sort of work is difficult to find. Moreover, given that hierarchical condition is regularly changing, the bank's administration is entreated to continually assess the bank's determination strategies on the premise of their legitimacy, fair-mindedness, extent of use, and cost.

Penultimately, its apparent to note that, recruitment and selection are tools used in picking the best candidates for a vacuum position in an organization or getting the appropriate applicants for a job after the candidates have been sieved and filtrated by the human resource team. Humans as we are, we are behavioural animals and so, individuals ought to undergo a constant scrutiny in as much as recruitment and selection process are not frowned upon in seeking for the best candidates for catapulting an organizational performance and effectiveness.

\section{References}

Adams, J .S. (1963). Toward an understanding of equity. Journal of Abnormal and Social Psychology, 67, 422-434. https://doi.org/10.1037/h0040968

Anyim, F. C., Ekwoaba, J. O., \& Ideh, D. A. (2012). The role of human resource planning in recruitment and selection process. British Journal of Humanities and Social Sciences, 6(2), 68-78.

Aphu, E. S. (2015). The Study of Time Management in Civil Service Institutions in Ghana: A Case of Accra Metropolitan Assembly. European Journal of Business and Management, $7(30)$..

Armstrong, M. (2006). A Handbook of Human Resource Management Practice. 10th ed. 
Great Britain: Cambridge University.

Asika, N. (1991). Research Methods in the Behavioural Sciences. Lagos: Learn Africa Plc.

Atkinson, J., \& Storey, D. (1994). Small Firms and Employment, Employment in the Small Firm and the Labour Market. London: Routledge.

Atkinson, R. L., Atkinson, R. C., Smith, E. E., \& Bem, D. J. (1999). Pszichológia. OsirisSzázadvég Kiadó, Második, javított kiadás, Budapest.

Bacon, N., \& Hoque, K. (2005). HRM in the SME sector: Valuable employees and coercive networks. The International Journal of Human Resource Management, 16(11), 1976- 1999. https://doi.org/10.1080/09585190500314706

Barber, A., Wesson, M., Roberson, Q., \& Taylor, S. (1999). A tale of two job markets: Organisational size and its effects on hiring practices and job search behaviour. Personnel Psychology, 52(4), 841-867. https://doi.org/10.1111/j.1744-6570.1999.tb00182.x

Barney, J. B. (1991). Firm resources and sustained competitive advantage. Journal of Management, 17(1), 99-120. https://doi.org/10.1177/014920639101700108

Barney, J. B. (2001). Resource-based theories of competitive advantage: a ten-year retrospective on the resource-based view. Journal of Management, 27(6), 643-650. https://doi.org/10.1177/014920630102700602

Biles, G. E., \& Holmberg, S. R. (1980): Strategic human resource planning. Glenn Ridge, New Jersey: Thomas Horton and Daughters.

Bohlander, G., Snell, S., \& Sherman, A. (2001). Managing human resources. New York: South- Western College.

Bowley, A. L. (1926). Measurements of precision attained in sampling. Bulletin of the International Statistics Institute, Amsterdam, 22, 1-62.

Boxall, P. \& Purcell, J., (2008). Strategy and human resource management. Bristol: Palgrave.

Catano, V. M., Wiesner, W. H., \& Hackett, R. D. (2010). Recruitment and selection in Canada (5th ed). Canada:

Deshpande, S., \& Golhar, D. Y. (1994). HRM practices in large and small manufacturing firms: A comparative study. Journal of Small Business management, 32(2), 49-56.

DeVaro, J. (2008). The labor market effects of employer recruitment choice. European Economic Review, 52(2), 283-314. https://doi.org/10.1016/j.euroecorev.2007.11.001

Djabatey, E. N. (2012). Recruitment and selection practices of organizations: A case study of HFC Bank (GH) Ltd. Unpublished thesis submitted to the Institute of Distance Learning, Kwame Nkrumah University of Science and Technology. Ghana: Kwame Nkrumah University of Science and Technology.

Elwood, \& James, A. P. (1996). Productivity gains from the implementation of employee 
training Programs. Industrial relations, 33(4), 411-425.

Ezeali, B. O., \& Esiagu, L. N. (2010). Public personnel management: Human capital management strategy in the 12st century. Onitsha: Book Point Limited.

Fidelity Bank Plc. (2013). Our History. Retrieved December 22014 from http://www.fidelitybankplc.com/ourhistory.asp

Gamage, A. S. (2014). Recruitment and selection practices in manufacturing SMEs in Japan: An analysis of the link with business performance. Ruhuna Journal of Management and Finance, 1(1), 37-52.

Healy, G. (1993). Business and discrimination. In Stacey, R. (Ed.), Strategic thinking and the management of change: International perspectives of organisational dynamics. London: Kogan Page.

Henry, O., \& Temtime, Z. (2009). Recruitment and selection practices in SMEs: Empirical evidence from a developing country perspective. Advances in Management, 3(2), 52-58.

Huselid, A. M. (1995). The impact of human resource management practices on turnover, productivity, and corporate financial performance. Academy of Management Journal, 38(3). 635-672.

Ichniowski, C., Shaw, K., \& Prennushi, G. (1999), The effects of human resource management practices on productivity: a study of steel finishing lines, American Economic Review, 87(3), 291-313.

Israel, G. D. (2013). Determining sample size. Florida: IFAS, University of Florida.

István, J. (2010). Selection methods used in recruiting sales team members. Periodica Oeconomica, October, 110-117.

Izueke, E. M. (2009). Strategic human resources management in the Nigerian Public Service and the millennium development goals (MDGs): The nexus. Nigerian Journal of Public Administration and Local Government. Xiv (1 \& 2).

Katou, A. A., \& Budhwar, P. S. (2006). Human resource management systems and organizational performance: A test of a mediating model in the Greek manufacturing context. International Journal of Human Resource Management, 17, 1223-1253. https://doi.org/10.1080/09585190600756525

Kepha, O., Mukulu, E., \& Waititu, G. A. (2014). The influence of recruitment and selection on the performance of employees in research institutes in Kenya. International Journal of Science and Research, 3(5), 132-138

McEvoy, M. G. (1984). Small business personnel practices. Journal of Small Business Management, 22(4), 1-8.

Montan, H., \& Charnou, B. (2002). Human resource practices and firm performance of multinational corporations: Influences of country of origin. Journal of International Human 
Resource Management, 9, 632-652.

Mullins, J. L. (1999). Management and organisational behaviour. London: Prentice Hall.

Mullins, L. J. (1999). Management and organizational behaviour. (5th Edition, Essex: Pearson Education.

Munyon, T. P., Summers, F. K. J., \& Gerald, R. (2011). Team staffing modes in organizations: Strategic considerations on individual and cluster hiring approaches, Human Resource Management Review, 21(3), 228-242. https://doi.org/10.1016/j.hrmr.2010.07.002

Nelson Education Ltd. Chartered Institute of Personnel and Development (2011). Diversity in the workplace: an overview. Factsheet. London: CIPD.

Obikeze, S. O., \& Obi, E. A. (2004). Public administration in Nigeria. A developmental Approach; Onitsha: Book Point Limited.

Ofori, D., \& Aryeetey, M. (2011). Recruitment and selection practices in small and medium enterprises. International Journal of Business Administration, 2(3), 45-60. https://doi.org/10.5430/ijba.v2n3p45

Okoh, A. O. (2005). Personnel and human resources management in Nigeria. Lagos: Amfitop Books

Omanović, V. (2009). Diversity and its management as a dialectical process: Encountering Sweden and the USA. Scandinavian journal of management, 25, 352-362. https://doi.org/10.1016/j.scaman.2009.09.001

Opatha, H. H. D. N. P. (2010). Human resource management. Colombo: Author published.

Osemeke, M. (2012). The impact of human resource management practices on organizational performance: A study of Guinness Nigeria Plc. International Journal of Arts and Humanities, l(1), 79-94.

Pearn, M. A. (1989). Fairness in employment selection: A comparison of UK and

Priyanath, H. M. S. (2006). Managerial deficiencies in the small and medium enterprises (SMEs) in Sri Lanka: An empirical evidence of SMEs in the Ratnapura District. Sabaragamuwa University Journal, 6(1), 93-105. https://doi.org/10.4038/suslj.v6i1.1692

Rauf, M. A. (2007). HRM sophistication and SME performance: A case of readymade garment manufacturers and exporters in Lahore. Pakistan Report, London: HMS

Richard, P. J., Devinney, T. M., Yip, G. S., \& Johnson, G. (2009). Measuring organizational performance as a dependent variable: Towards methodological best practice. Journal of Management, 35, 718-804. https://doi.org/10.1177/0149206308330560

Robbins, S. P. (2005). Organizational behaviour: Concepts, controversies and applications. New Jersey: Prentice Hall.

Sang, C. (2005). Relationship between human resource management practices and perception 
of organizational Taiwan performance, roles of management style, social capital, and culture: Comparison between manufacturing firms in Cambodia and Taiwan. Taiwan: National Cheng Kung University.

Sarkar, A., \& Kumar, S. (2007). Effective recruitment and selection: An approach towards model building. HRM Review, 7(7), 15-22.

Sen, S., \& Saxena, S. (1997). Managing knowledge workers. Personnel Today, IIPM, 28.

Sinha, V., \& Thaly, P. (2013). A review on changing trend of recruitment practice to enhance the quality of hiring in global organizations. Management, 18(2), 141-156. USA experience. In. Smith, M., Robertson, I. T. (Eds) Advances in selection and assessment.

Straw, J. (1989). Equal opportunities: The way ahead. London: Institute of Personnel Management.

Subbarao, P. (2006). Essentials of human resource management and industrial relation. Mumbai: Himalaya Publications.

Syed, Z. J. W. (2012). Universalistic perspective of HRM and organizational performance: meta- analytical study. International Bulletin of Business Administration, 13

Teixeira, A. (2002). On the link between human capital and firm performance; A theoretical and empirical survey. FEP Working Paper, 121, November, 1-38.

Tendon, V. (2006). Talent deficiency syndrome: Effective executive. ICFAI Press, 8(5), $12-20$.

Terpstra, E. D., \& Rozell, J. E. (1993). The relationship of staffing practices to organizational level measures of performance. Personnel Psychology, 46(1), 27- 48. University of Ireland. (2006). Recruitment and selection procedures. Maynooth, Ireland: National University of Ireland.

Unwin, K. (2005). Recruiting knowledge workers. HRM Review, 5(10), 5-9.

Vyas, A. M. (2011). Human resource recruitment in India: Critical role of online recruitment system, 1(6), 1-4.

Wright, P. M., Gardner, T. M., Moynihan, L. M., \& Allen, M. R. (2005). The relationship between HR Practices and firm performance: Examining causal order. Personnel Psychology, 58(2), 409-47. https://doi.org/10.1111/j.1744-6570.2005.00487.x

Yamane, T. (1967). Statistics: An introductory analysis, 2nd Edition, New York: Harper and Row.

Zottoli, M. A., \& Wanous, J. P. (2000). Recruitment source research: Current status and future directions. Human Resource Management Review, 10(4), 353-382. https://doi.org/10.1016/S1053-4822(00)00032-2 


\section{Copyright Disclaimer}

Copyright for this article is retained by the author(s), with first publication rights granted to the journal.

This is an open-access article distributed under the terms and conditions of the Creative Commons Attribution license (http://creativecommons.org/licenses/by/4.0/). 